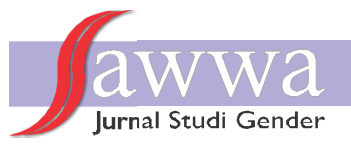

\title{
Mencegah Tindak Kekerasan pada Anak di Lembaga Pendidikan
}

\author{
Khaerul Umam Noer \\ Universitas Muhammadiyah Jakarta, \\ Jakarta - Indonesia \\ email: umam.noer@umj.ac.id
}

\begin{abstract}
The role of Pusat Pelayanan Terpadu Pemberdayaan Perempuan dan Anak (P2TP2A)-translated in English: the Integrated Service Center for the Empowerment of Women and Children - in the context of development is very important in order to oversee the government's steps in minimizing and handling cases of violence against women and children which are getting higher intensity from year to year, especially in educational institutions in the form of peer violence and violence by teacher. This study seeks to describe the collaboration of P2TP2A and the Education Office of Depok City in preventing violence against children in educational institutions. Observation and documentation studies are used as data collection techniques and qualitative descriptive analysis. This study produces findings including: 1) collaboration of P2TP2A and the Education Agency in the prevention of violence against children in the educational environment carried out in the form of socialization "Stop violence on children" and the establishment of children's Forums; 2) involvement of P2TP2A in the recruitment of teachers and principals. The form of collaboration still needs to be improved, especially in the preparation of hidden curriculum programs for handling violence, budgeting violence prevention activities for children in the school environment, and strengthening the authority of prevention until the handling of violence against women and children. This collaboration is at least a starting point that Depok becomes one of the regions that is highly committed in realizing Child Friendly Cities so that children's rights in the context of education can be fulfilled and the number of violence against children can be minimized.
\end{abstract}

Keywords: child abuse; Pusat Pelayanan Terpadu Pemberdayaan Perempuan dan Anak (P2TP2A); educational institution; Depok City

Abstrak: Peranan Pusat Pelayanan Terpadu Pemberdayaan Perempuan dan Anak (P2TP2A) dalam konteks pembangunan sangat penting guna mengawal langkah pemerintah dalam meminimalisir dan menangani kasus kekerasan perempuan dan anak yang semakin tinggi intensitasnya dari tahun ke tahun, terutama di lembaga pendidikan dalam bentuk kekerasan antar teman dan kekerasan oleh guru. Penelitian ini mendeskripsikan kolaborasi P2TP2A dan Dinas Pendidikan Kota Depok dalam mencegah kekerasan terhadap anak-anak di lembaga pendidikan. Metode observasi dan dokumentasi 
digunakan sebagai teknik pengumpulan data serta analisis deskriiptif kualitatif. Temuan penelitian ini di antaranya: 1) kolaborasi P2TP2A dan Dinas Pendidikan dalam pencegahan kekerasan terhadap anak di lembaga pendidikan dilakukan dalam bentuk sosialisasi "Stop kekerasan pada Anak" dan pembentukan forum anak, 2) pelibatan P2TP2A dalam rekrutmen guru dan kepala sekolah. Kolaborasi tersebut masih perlu ditingkatkan terutama dalam penyusunan program hidden kurikulum penanganan kekerasan, penganggaran kegiatan pencegahan kekerasan pada anak di lingkungan sekolah, dan penguatan kewenangan pencegahan sampai penangaan kekerasan terhadap perempuan dan anak. Kolaborasi ini setidaknya menjadi titik awal bahwa Depok menjadi salah satu wilayah yang berkomitmen tinggi dalam mewujudkan Kota Layak Anak sehingga hak-hak anak dalam konteks pendidikan dapat terpenuhi dan angka kekerasan terhadap anak dapat diminimalisir.

Kata Kunci: kekerasan pada anak; Pusat Pelayanan Terpadu Pemberdayaan Perempuan dan Anak (P2TP2A); lembaga pendidikan; Kota Depok

\section{A. Pendahuluan}

Kekerasan terhadap perempuan dan anak di Indonesia semakin hari semakin memprihatinkan. Pada tahun 2018 Komnas Perempuan merilis terdapat 348.446 kasus kekerasan terhadap perempuan yang tersebar di 34 provinsi di Indonesia. ${ }^{1}$ Komnas Perlindungan Anak mencatat dari Januari hingga Mei 2018 di wilayah Jabodetabek, Kota Depok menduduki peringkat ke-4 sebagai kota dengan jumlah pelanggaran anak tertinggi dengan rata-rata 30 kasus terlaporkan setiap bulan. ${ }^{2}$ Sebanyak 52\% merupakan kasus kekerasan seksual terhadap anak, dan 48\% merupakan kasus kriminal berupa tindakan pembegalan dan penjarahan toko, di mana rata-rata pelaku berumur 14-17 tahun. Dinas Perlindungan Anak, Pemberdayaan Masyarakat dan Keluarga (DPAPMK) Kota Depok menunjukkan data yang lebih kecil, terhitung JanuariJuni 2018 terdapat sebanyak 27 kasus kekerasan pada anak, ${ }^{3}$ dengan perincian

${ }^{1}$ Komisi Nasional Anti Kekerasan terhadap Perempuan, "Lembar Fakta dan Catatan Tahunan Komnas Perempuan Tahun 2018” (Jakarta: Komnas Perempuan, 2018).

2KPAI, “Laporan Tahunan Komisi Nasional Perlindungan Anak Indonesia Tahun 2017” (Jakarta: Komisi Nasional Perlindungan Anak Indonesia, 2018).

${ }^{3}$ Aco Ardiansyah, "Implementasi Kebijakan Pelayanan Terpadu Pemberdayaan Perempuan dan Anak dalam Pencegahan Kekerasan Anak di Kota Depok” (Tesis tidak dipublikasikan, Universitas Muhammadiyah Jakarta, 2019). 
5 kasus kekerasan fisik, 19 kasus kekerasan seksual, 1 kasus perundungan, 1 kasus pornografi, dan 1 kasus kenakalan remaja.

Kekerasan pada perempuan dan anak adalah fenomena yang kompleks, sebab kekerasan tidak terjadi secara tiba-tiba dan tidak dapat ditangani secara sporadik dan sepihak. Kompleksitas masalahnya muncul mulai dari pencegahan, penanganan, dan rehabilitasi korban. Begitu kompleksnya persoalan ini, sehingga upaya untuk menyelesaikan persoalan kekerasan sangat multisektor dan multistakeholder. Salah satu lembaga kunci dalam upaya ini adalah Pusat Pelayanan Terpadu Pemberdayaan Perempuan dan Anak (selanjutnya disingkat P2TP2A).

Persoalannya adalah, sebagai lembaga, P2TP2A belum secara serius didalami peran dan fungsinya. Hal ini ditandai dengan sedikitnya kajian mengenai lembaga ini. Diantaranya adalah kajian dari Hendrya, ${ }^{4}$ Priharyanto, ${ }^{5}$ Rizkah, ${ }^{6}$ Yelfia, ${ }^{7}$ dan Rosnawati ${ }^{8}$ yang mengkaji P2TP2A pada sisi kekerasan seksual dan kekerasan dalam rumah tangga. Selain itu, masih ada pula penelitian yang dilakukan oleh Huda, ${ }^{9}$ Muhammad, ${ }^{10}$ dan Afrilia, ${ }^{11}$ yang mengkaji mengenai

${ }^{4}$ Pepi Hendrya, "Pemberdayaan Perempuan Korban Kekerasan dalam Rumah Tangga (KDRT), dalam Perspektif Ketahanan Individu: Studi Kasus Perempuan Korban KDRT Klien P2TP2A DKI Jakarta" (Tesis tidak dipublikasikan, Universitas Indonesia, 2011).

${ }^{5}$ Saptadi Agung Priharyanto, "Peran Aparat Penegak Hukum dan Pendamping Korban dalam Penanganan KDRT: Studi Kasus LBH APIK Jakarta, P2TP2A Provinsi DKI Jakarta dan Unit PPA Bareskrim Polri” (Tesis tidak dipublikasikan, Universitas Indonesia, 2011).

${ }^{6}$ Nur Rizkah. S, "Kinerja Pusat Pelayanan Terpadu Pemberdayaan Perempuan dan Anak (P2TP2A) (Studi Kasus: Kekerasan Seksual di Kabupaten Sinjai)" (Skripsi tidak dipublikasikan, Universitas Hasanuddin, 2016).

${ }^{7}$ Oka Yelfia, "Pengalaman perempuan dalam menghadapi kekerasan dalam rumah tangga (KDRT) di Pusat Pelayanan Terpadu Pemberdayaan Perempuan dan Anak (P2TP2A) Limpapeh Rumah Nan Gadang tahun 2015" (Skripsi tidak dipublikasikan, Universitas Andalas, 2016).

${ }^{8}$ Emy Rosnawati, "Peran Pusat Pelayanan Terpadu Pemberdayaan Perempuan dan Anak (P2TP2A) dalam Mengatasi Kekerasan dalam Rumah Tangga," Kosmik Hukum 18, no. 1 (2018), https://doi.org/10.30595/kosmikhukum.v18i1.2341.

${ }^{9}$ Nurul Huda, "Kekerasan terhadap Anak dan Masalah Sosial yang Kronis," Pena Justisia Jurnal Media Komunikasi dan Kajian Hukum 7, no. 14 (2008).

${ }^{10}$ Muhammad Muhammad, "Aspek Perlindungan Anak dalam Tindak Kekerasan (Bullying) terhadap Siswa Korban Kekerasan di Sekolah (Studi Kasus di SMK Kabupaten Banyumas)," Jurnal Dinamika Hukum 9, no. 3 (2009): 230-36, https://doi.org/10.20884/1.jdh.2009.9.3.234.

${ }^{11}$ Anggita Putri Afrilia, "Implementasi Program Pencegahan Kekerasan terhadap Anak di Pusat Pelayanan Terpadu Pemberdayaan Perempuan dan Anak (P2TP2A) DKI Jakarta” (Skripsi tidak dipublikasikan, Universitas Indonesia, 2012). 
faktor-faktor yang berhubungan dengan perilaku petugas dalam penanganan kasus kekerasan pada anak di P2TP2A. Kajian mengenai implementasi kerja P2TP2A dapat dilihat dari tulisan Saida, ${ }^{12}$ Hartati, ${ }^{13}$ Fahmi, ${ }^{14}$ dan Aliyah. ${ }^{15}$

Sedikitnya penelitian mengenai P2TP2A sesungguhnya mengherankan sekaligus mengkhawatirkan, sebab P2TP2A adalah badan yang secara nasional ada di hampir seluruh wilayah di Indonesia, dan dengan tugas pokok dan fungsi yang sangat fundamental, mulai dari hulu hingga ke hilir. Tugas utama P2TP2A mencakup pencegahan, penanganan, dan rehabilitasi korban kekerasan. Korban kekerasan pun tidak hanya perempuan, namun juga anak-anak. Dengan yang demikian, kompleksitas persoalan P2TP2A tidak dapat dilokasir. Penelitian ini sendiri berfokus pada satu isu krusial: bagaimana menangani kekerasan terhadap anak yang terjadi di lembaga pendidikan. Persoalan ini dengan demikian bukan hanya ranah kerja P2TP2A, namun juga Dinas Pendidikan sebagai pihak terkait. Utamanya dalam upaya mencegah tindak kekerasan terhadap anak.

Tulisan ini menitikberatkan pada dua hal: Pertama, fokus pada P2TP2A, sebuah organisasi yang dimandatkan melalui Peraturan Wali Kota Depok No. 43 Tahun 2017. Dalam mandat tersebut, upaya pemberantasan tindak kekerasan harus dilakukan multisektor. Kedua, sebagai jawaban atas mandat tersebut, tulisan ini berfokus pada upaya kolaborasi antara P2TP2A dan Dinas Pendidikan dalam memberantas kekerasan terhadap anak, utamanya di lembaga pendidikan. Dalam upaya tersebut, maka P2TP2A mutlak harus bekerjasama dengan Dinas Pendidikan Kota Depok. Maka penelitian ini mencoba melihat dua hal sekaligus: Pertama, bagaimana P2TP2A bekerja dan berkolaborasi dengan

${ }^{12}$ Abdul Rachman Saida, "Analisis Kinerja pada Kantor Pusat Pelayanan Terpadu Pemberdayaan Perempuan dan Anak (P2TP2A) Provinsi Sulawesi Tengah," Katalogis 3, no. 9 (2015): 54-67, http://jurnal.untad.ac.id/jurnal/index.php/Katalogis/article/view/6418.

13Misriyani Hartati, "Studi tentang Upaya Penanganan Tindak Kekerasan terhadap Perempuan dan Anak: Studi Kasus pada Pusat Pelayanan Terpadu Pemberdayaan Perempuan dan Anak (P2TP2A) Provinsi Kalimantan Timur," eJournal Imu Pemerintahan - Fisip Universitas Mulawarman 1, no. 3 (2013).

${ }^{14}$ Ahadin Syarifudin Fahmi, "Faktor-faktor yang Berhubungan dengan Perilaku Petugas dalam Penanganan Kasus Kekerasan pada Anak di P2TP2A (Pusat Perlindungan Terpadu Pemberdayaan Perempuan dan Anak) Kabupaten Sidoarjo" (Universitas Diponegoro, 2014), http://eprints. undip.ac.id/53479/.

${ }^{15}$ Himma Aliyah, “Upaya Pusat Pelayanan Terpadu Pemberdayaan Perempuan dan Perlindungan Anak dalam Mewujudkan Keadilan Restoratif terhadap Rehabilitasi Korban Tindak Kejahatan Perkosaan" (Skripsi tidak dipublikasikan, Universitas Islam Negeri Malang, 2017). 
Dinas Pendidikan di Kota Depok? Kedua, bagaimana peluang dan hambatan yang dihadapi oleh kedua lembaga ini dalam upaya kolaborasi memberantas tindak kekerasan teradap anak di lembaga pendidikan? Hal ini penting, sebab P2TP2A adalah badan fungsional yang secara tegas bertanggungjawab dalam melaksanakan pencegahan, penanganan, dan rehabilitas korban kekerasan. Dalam upaya tersebut, maka P2TP2A harus berkoordinasi dengan banyak pihak, sebagai upaya menurunkan angka kekerasan terhadap perempuan dan anak di Kota Depok.

Kementerian Pemberdayaan Perempuan dan Perlindungan anak sebagai salah satu lembaga negara yang bertanggungjawab terhadap penanganan kekerasan anak dan perempuan mengambil langkah untuk penanganan kekerasan anak dan perempuan dengan mengeluarkan Peraturan Menteri KPPPA No. 5 Tahun 2010 tentang Panduan Pembentukan dan Pengembangan Pusat Layanan Terpadu untuk memberikan layanan terpadu terhadap korban kekerasan. Peraturan inilah yang kemudian menjadi panduan di seluruh Kabupaten/Kota untuk membentuk Pusat Pelayanan Terpadu Pemberdayaan Perempuan dan Anak (P2TP2A). Di Kota Depok, keberadaan P2TP2A berada di bawah naungan Dinas Perlindungan Anak, Pemberdayaan Masyarakat dan Keluarga (DPAPMK). Dengan demikian, P2TP2A adalah suatu unit kerja fungsional yang menyelenggarakan pelayanan terpadu untuk saksi dan/atau korban tindak kekerasan dan dibentuk dalam rangka memberikan layanan terpadu korban kekerasan berupa layanan pengaduan, layanan rehabilitasi kesehatan, layanan rehabilitasi sosial, layanan bantuan hukum, pemulangan, dan reintegrasi sosial.

Pembentukan P2TP2A juga menjadi sebuah keharusan akibat maraknya kekerasan pada perempuan dan anak-anak, sekaligus menjadi implementasi atas tanggungjawab Negara dalam melindungi perempuan dan anak-anak. Dalam konstitusi, Negara berkewajiban mengembangkan sistem jaminan sosial bagi seluruh rakyat dan memberdayakan masyarakat yang lemah dan tidak mampu sesuai dengan martabat kemanusiaan. Sebagai turunan dari amanat konstitusi, pemerintah Indonesia mengembangkan sejumlah instrumen kebijakan, baik berupa undang-undang, kebijakan kementerian, hingga peraturan daerah.

Beberapa Undang-undang yang berkaitan erat dengan P2TP2A dan upaya negara melindungi perempuan dan anak antara lain adalah UU No. 23 Tahun 2002 tentang Perlindungan Anak. UU ini mengamanatkan Negara untuk 
menjamin dan melindungi anak agar dapat tumbuh berkembang tanpa adanya kekerasan dan diskriminasi dari berbagai pihak, mulai dari keluarga, komunitas, lembaga pendidikan, bahkan Negara itu sendiri. Semua anak harus dilindungi, baik itu anak terlantar, cacat, unggulan, angkat, asuh, semuanya harus dilindungi sebagaimana HAM untuk seluruh masyarakat. UU No. 23 Tahun 2004 tentang Penghapusan Kekerasan Dalam Rumah Tangga menyatakan pemerintah bertanggungjawab dalam pencegahan KDRT, dalam upaya tersebut, pemerintah melakukan: (a) merumuskan kebijakan tentang penghapusan KDRT, (b) menyelenggarakan komunikasi, informasi, dan edukasi tentang KDRT; (c) menyelenggarakan sosialisasi dan advokasi tentang KDRT; (d) menyelenggarakan pendidikan dan pelatihan sensitif gender dan isu KDRT serta menetapkan standar dan akreditasi pelayanan yang sensitif gender. UU No. 44 Tahun 2008 tentang Pornografi mewajibkan pemerintah, lembaga sosial, lembaga pendidikan, lembaga keagamaan, keluarga, dan/atau masyarakat memberikan pembinaan, pendampingan, serta pemulihan sosial, kesehatan fisik dan mental bagi setiap anak yang menjadi korban atau pelaku pornografi. Permen KPPPA No. 05 Tahun 2010 tentang Panduan Pembentukan Dan Pengembangan Pusat Pelayanan Terpadu dan Permen KPPPA No. 02 Tahun 2011 tentang Pedoman Penanganan Anak Korban Kekerasan menjelaskan kewajiban Negara dalam melindungi anak-anak, terutama anak korban kekerasan, yang meliputi pelayanan identifikasi, rehabilitasi kesehatan, rehabilitasi sosial, pemulangan, bantuan hukum, dan reintegrasi sosial.

Jika memperhatikan berbagai produk kebijakan, maka jelas terlihat pemerintah dan masyarakat mempunyai peran penting dalam pencegahan Kekerasan anak dan perempuan. Dalam rangka mengimplementasikan amanat UU dan peraturan yang ada di atas, maka penting kiranya setiap daerah membentuk institusi yang khusus dalam mencegah dan menangani tindak kekerasan terhadap perempuan dan anak yang dituangkan dalam sebuah kebijakan yang berbentuk Peraturan Daerah serta turunan lainnya, serta kerjasama antar institusi dalam menjalankan amanat UU juga menjadi sangat penting, agar penanganan terhadap kejadian ini menjadi lebih serius dan dapat menunjukkan kemajuan yang siginifikan dengan berkurangnya korban kekerasan terhadap anak dan perempuan.

Pemerintah Kota Depok membentuk P2TP2A melalui Peraturan Walikota Depok No. 43 Tahun 2017 tentang Pusat Pelayanan Terpadu Pemberdayaan Perempuan dan Anak. Pembentukan P2TP2A dimaksudkan untuk melaksana- 
kan sebagian tugas Pemerintah Daerah dalam mewujudkan kesetaraan dan keadilan gender dengan mengintegrasikan strategi Pengarusutamaan Gender (PUG) dan Pengarusutamaan Hak Anak (PUHA) dalam berbagai kegiatan pelayanan terpadu bagi peningkatan kondisi, peran dan perlindungan perempuan serta memberikan kesejahteraan dan perlindungan anak. Sedangkan tujuan dibentuknya P2TP2A yaitu untuk memberikan pelayanan yang cepat, tepat dan terpadu dalam rangka perlindungan perempuan dan anak yang rentan terhadap tindak kekerasan. Untuk mengimplementasi seluruh program kerja P2TP2A, maka kerjasama dengan stakeholder lain adalah hal yang mutlak dilakukan. Hal inilah yang coba dieksplorasi dalam tulisan ini.

Tulisan ini didasarkan pada hasil penelitian yang dilakukan di Kota Depok, Provinsi Jawa Barat sepanjang Februari-September 2018. Menggunakan metode penelitian kualitatif, penelitian ini mencoba mengumpulkan sejumlah data terkait peran P2TP2A dan Dinas Pendidikan. Dalam mengumpulkan data telah digunakan teknik wawancara, observasi dan dokumentasi. Informan dalam penelitian ini mencakup Kepala P2TP2A Kota Depok, Kepala DPAPMK Kota Depok, Kepala Dinas Pendidikan, Kepala Bidang Perencanaan, Evaluasi dan Pelaporan Dinas Pendidikan Kota Depok, Kepala Bidang Tenaga Pendidik dan Kependidikan Dinas Pendidikan Kota Depok. Observasi dilakukan dengan cara mengikuti agenda, dan melihat secara langsung bagaimana Dinas Pendidikan dan P2TP2A menjalankan program kebijakannya dalam rangka pencegahan kekerasan terhadap anak. Misalnya dalam sosialisasi pencegahan terhadap tindak kekerasan anak. Penulis mendatangi langsung serta menjadi peserta dalam sosialisasi tersebut untuk melihat secara langsung bagaimana sosialisasi dilakukan, materi yang diberikan dan siapa saja yang menjadi peserta sosialisasi tersebut. Penelitian ini juga mempergunakan data dokumen, antara lain: dokumen perencanaan, berupa rencana strategis, rencana kerja, program kerja, dokumen kebijakan seperti Perda, Perwal, Surat Keputusan yang terkait dengan pencegahan kekerasan dan juga bahan-bahan yang digunakan dalam mengimplementasikan program dan kebijakan tersebut.

\section{B. Kebijakan P2TP2A Kota Depok}

Pembentukan P2TP2A dengan salah satu fokus kerjanya pada perlindungan anak adalah amanat langsung dari UU No. 23 Tahun 2002 tentang Perlindungan Anak yang kemudian diubah menjadi UU No. 35 Tahun 2014 
tentang Perlindungan Anak. UU tersebut mengamanatkan negara secara aktif melindungi anak dari tindak kekerasan, baik yang terjadi dalam ranah domestik maupun publik. Sebelum UU No. 35 Tahun 2014 lahir, telah ada Peraturan Menteri Pemberdayaan Perempuan dan Perlindungan Anak Nomor 5/2010 tentang Pembentukan Pengembangan Pusat Pelayanan Terpadu (PPT) yang menjadi landasan terbentuknya P2TP2A di setiap level pemerintahan.

Setelah revisi UU No. 23 Tahun 2002 menjadi UU No. 35 Tahun 2014, pemerintah melalui Instruksi Presiden No. 18 Tahun 2014 tentang Perlindungan dan Pemberdayaan Perempuan dan Anak Dalam Konflik Sosial mewajibkan pemerintah di setiap level untuk lebih berfokus pada upaya perlindungan anak dengan multistakeholder. Hal ini diturunkan ke dalam Permen PPPA No. 6 Tahun 2015 tentang Sistem Pemberdayaan Perempuan dan Perlindungan Anak. Permen ini mengatur bahwa dalam rangka mengefektifkan pemberdayaan perempuan dan dan perlindungan anak maka diperlukan suatu sistem yang komperhensif dan integratif, mulai dari tahap pelayanan penanganan laporan/pengaduan, pelayanan kesehatan, rehabilitasi sosial, penegakan dan bantuan hukum, sampai dengan pemulangan dan reintegrasi sosial bagi perempuan dan anak korban kejahatan dan kekerasan ke lingkungan sosialnya.

Sistem pemberdayaan perempuan dan perlindungan anak diwujudkan salah satunya melalui pembentukan unit layanan teknis yang terintegrasi, satu atap dan berjejaring yang dibentuk oleh pemerintah, pemerintah daerah, masyarakat, lembaga swadaya masyarakat, lembaga donor atau lembagalembaga lainnya, yaitu Pusat Pelayanan Terpadu Pemberdayaan Perempuan dan Anak (P2TP2A) atau lembaga sejenisnya yang memiliki fungsi dan peran yang sama. Kedudukan P2TP2A berada di tingkat Pemerintahan Provinsi, Kabupaten dan juga Kecamatan. P2TP2A berada di bawah koordinasi satuan kerja perangkat daerah (SKPD) atau unit-unit lainnya yang menangani pemberdayaan perempuan dan perlindungan anak

Selain itu dalam peraturan ini juga mengatur tentang bagaimana struktur kelembagaan P2TP2A, yaitu dibentuk berdasarkan Keputusan Gubernur/ Bupati/Walikota/Camat yang mana Keanggotaannya dapat berasal dari unsur struktural dan non struktural yang berasal dari kalangan profesi, akademisi, tokoh masyarakat. dan sumber pembiayaan pembentukan, pengembangan dan penguatan P2TP2A Provinsi Kabupaten, Kota, dan Kecamatan bersumber dari Anggaran Pendapatan dan Belanja Daerah (APBD) dan/ atau sumber lainnya yang tidak mengikat berdasarkan ketentuan peraturan perundang-undangan. 
Untuk menterjemahkan amanat UU, Instruksi Presiden dan Permen PPPA, maka Wali Kota Depok mengeluarkan Peraturan Wali Kota No. 43 Tahun 2017 tentang Pusat Pelayanan Terpadu Pemberdayaan Perempuan dan Anak (P2TP2A). Dalam Perwali ini, pelayanan terpadu adalah serangkaian kegiatan untuk melakukan perlindungan bagi korban kekerasan termasuk tindak pidana perdagangan orang yang dilaksanakan secara bersama-sama oleh instansi atau lembaga terkait sebagai suatu kesatuan penyelenggara. P2TP2A adalah salah satu bentuk wahana pelayanan bagi perempuan dan anak dalam upaya pencegahan, penanggulangan, pelayanan korban tindak kekerasan serta pemenuhan informasi dan kebutuhan di bidang keterampilan, kesehatan, ekonomi, politik, hukum, bagi perempuan dana anak korban tindak kekerasan di Kota Depok.

Tugas utama P2TP2A adalah memberikan pelayanan fisik, psikis, pendampingan hukum, rehabilitasi sosial, reintegrasi, rujukan, konsultan, advokasi, pendidikan dan pelatihan serta membantu penyelesaian permasalahan kekerasan pada perempuan dan anak. Dalam melaksanakan peran tersebut, P2TP2A Kota Depok memiliki empat divisi khusus: pelayanan sosialiasi, pelayanan rujukan kesehatan, pelayanan bantuan hukum, dan pelayanan rehabilitasi. Khusus untuk pelayanan bantuan hukum, terdapat empat jejaring kerja, yaitu: pengadilan, kejaksaan, unit perlindungan perempuan dan anak di kepolisian, dan lembaga bantuan hukum.

Fungsi dan tugas P2TP2A semakin ditambah seiring dengan perubahan Permen PPPA No. 6 Tahun 2015 menjadi Permen PPPA No. 4 Tahun 2018 Tentang Pedoman Pembentukan Unit Pelaksana Teknis Daerah Perlindungan Perempuan dan Anak. dalam Peraturan tersebut dibahas bahwa Unit Pelaksana Teknis Daerah Perlindungan Perempuan dan Anak (UPTD PPA) sebagai unit pelaksana teknis daerah yang dibentuk pemerintah daerah dalam memberikan layanan bagi perempuan dan anak yang mengalami kekerasan, diskriminasi, perlindungan khusus, dan masalah lainnya. Kedudukan UPTD PPA berada di bawah dan bertanggung jawab kepada Kepala Dinas yang menyelenggarakan urusan pemerintahan di bidang pemberdayaan perempuan dan perlindungan anak di tingkat daerah provinsi dan derah kabupaten/kota.

Dalam Permen tersebut diatur, bahwa dalam penyelenggaraan tugas-tugas P2TP2A harus pula bekerjasama dengan dinas terkait, di antaranya Dinas 
Pendidikan. Hal ini didukung oleh Peraturan Menteri Pendidikan dan Kebudayaan No. 82 Tahun 2018 Tentang Pencegahan dan Penanggulangan Tindak Kekerasan di Lingkungan Satuan Pendidikan. Dalam Permen ini diatur bahwa Dinas Pendidikan harus berkoordinasi dengan P2TP2A, yang dalam aturan yang baru berada di bawah koordinasi DPAPMK Kota Depok.

\section{Kolaborasi: Memetakan Peluang dan Hambatan}

Salah satu persoalan paling krusial mengenai P2TP2A adalah sifat implementasinya yang sangat multisektor. Amanat Permen PPPA No. 4 Tahun 2018 dan Permen P\&K No. 82 Tahun 2018 mengisyaratkan bahwa upaya untuk memberantas tindak kekerasan di lembaga pendidikan menjadi tanggungjawab dua lembaga yang harus berkolaborasi satu sama lain. Dalam hal ini adalah P2TP2A yang bernaung di bawah DPAPMK dan Dinas Pendidikan.

Dalam pelaksanaan program kerja yang dilakukan oleh P2TP2A dan Dinas Pendidikan sepanjang pemantauan dan pengamatan yang dilakukan di lapangan berjalan dengan baik. Program kerja yang dijalankan oleh P2TP2A masih mengacu pada program kerja yang dibuat oleh DPAPMK Kota Depok - hal tersebut disebabkan, karena P2TP2A dalam Permen PPPA No. 6 Tahun 2015 tidak memiliki kewenangan dalam hal perumusan kebijakan terkait pemberdayaan perempuan dan perlindungan anak, sehingga kebijakan P2TP2A mengikuti arah kebijakan DPAPMK. Di sisi lain, model ini relatif menguntungkan, sebab baik DPAPMK maupun Dinas Pendidikan berada pada level yang sama sehingga mempermudah koordinasi. Hal ini membuka peluang untuk mempermudah koordinasi pelaksanaan program di lapangan.

Setidaknya terdapat empat program hasil kolaborasi antara P2TP2A dan Dinas Pendidikan yang dilaksanakan sepanjang 2018. Pertama, adalah program unggulan P2TP2A dan Dinas Pendidikan berupa sosialisasi Stop Kekerasan pada Anak (SKPA) dilakukan di sekolah-sekolah. Selain dengan Dinas Pendidikan, P2TP2A juga bekerjasama dengan para pendongeng, Polresta, psikolog P2TP2A, dan Forum Anak Kota Depok untuk menyampaikan pentingnya kewaspadaan menjaga diri dan tindakan yang harus dilakukan bila menghadapi perlakuan tidak baik, terutama di dalam dan sekitar lingkungan sekolah.

Kedua, adalah program Srikandi Goes to School yang merupakan kerjasama dengan Srikandi Polisi Resort Kota Depok dalam rangka sosialisasi pencegahan kekerasan anak di ruang publik. Dalam program ini, P2TP2A berkoordinasi dengan Dinas Pendidikan untuk secara rutin menjadwalkan sekolah mana yang 
bisa dilakukan sosialisasi. Dinas Pendidikan yang menentukan sekolah mana yang dapat dikunjungi atau sekolah mana yang tidak, sebab dikhawatirkan jika tidak ada informasi dari Dinas Pendidikan kegiatan tersebut bertenturan dengan jadwal ujian atau kegiatan yang lain.

Ketiga, adalah pelibatan pelajar dalam Forum Anak Kota Depok. Forum Anak Kota Depok adalah bagian dari Forum Anak Nasional, sebuah organisasi yang diinisiasi dan dibina melalui Kementerian PPPA untuk menjembatani komunikasi dan interaksi antara pemerintah dan anak-anak. Berdasarkan Perwali, Forum Anak berada di bawah tanggungjawab P2TP2A, dan untuk menyukseskan Forum Anak, maka P2TP2A menggandeng Dinas Pendidikan untuk membentuk Forum Anak yang diisi oleh siswa-siswa yang mewakili setiap sekolah di tingkat kecamatan dan juga dari berbagai organisasi anak, sepanjang mereka masih berstatus anak yang ada di Kota Depok. Tugas utama Forum Anak adalah membentuk dua inisiatif pada anak, yakni sebagai Pelapor dan Pelopor. Sebagai Pelapor, Forum Anak mendorong setiap anak sebagai jembatan dalam melakukan pelaporan atas tindak kekerasan yang terjadi dengan menjadi agen aktif, misalnya mereka melihat atau mengetahui maka mereka harus langsung melaporkan ke P2TP2A. Sebagai Pelopor, anak didorong untuk mempelopori budaya tanpa kekerasan di lingkungan rumah, sekolah, dan komunitas. Forum Anak secara langsung didesain mendukung implementasi Depok sebagai Kota Layak Anak, salah satunya Forum Anak mensosialisasikan perlindungan anak dan kreatifitasnya, sekaligus sekaligus menjadi wadah untuk anak berorganisasi.

Keempat, adalah kerjasama strategis antara P2TP2A dan Dinas Pendidikan dalam seleksi guru non-ASN maupun kepala sekolah di lingkungan Dinas Pendidikan. Hal ini diawali dengan permintaan dari P2TP2A dengan adanya fakta bahwa banyak kasus kekerasan di lembaga pendidikan justru dilakukan oleh guru di dalam lembaga tersebut. P2TP2A sudah berulang kali meminta agar Dinas Pendidikan memperketat proses seleksi guru dan kepala sekolah untuk meminimalisir kasus kekerasan yang dilakukan oleh oknum guru. Pada awalnya, Dinas Pendidikan tidak merespon karena beranggapan bahwa masih banyak hal yang lebih penting untuk dikerjakan dibandingkan hal tersebut, padahal dalam satu kasus pelecehan seksual terhadap murid yang dilakukan oleh guru, justru pihak sekolah melindungi guru tersebut. 
P2TP2A mengusulkan kepada Dinas Pendidikan untuk dilibatkan dalam proses seleksi maupun rekrutmen guru dan kepala sekolah, dengan menggunakan MMPI (Minnesota Multiphasic Personality Inventory) dalam penerimaan guru non-ASN. MMPI adalah tes psikometri yang digunakan untuk mengukur psikopatologi orang dewasa, tujuannya adalah untuk memberikan gambaran tentang dimensi kepribadian dan psikopatologi yang penting dalam klinik psikiatri secara akurat. Saat ini, rekrutmen guru non-ASN dan kepala sekolah dilakukan Dinas Pendidikan bersama-sama dengan P2TP2A dengan melakukan psikotes dan wawancara kepada calon guru dan kepala sekolah tersebut, untuk mengetahui kecenderungan dan kejiwaan guna identifikasi sejak dini dan mencegah sejak dini terjadinya kekerasan di lingkungan sekolah.

Meski di sejumlah program terdapat kolaborasi yang sangat baik antara P2TP2A dan Dinas Pendidikan, namun sejumlah kendala masih seringkali dijumpai. Salah satu kendala terberat justru terletak di Dinas Pendidikan. Meski Dinas Pendidikan sangat berperan dalam mencegah kekerasan terhadap anak di lembaga pendidikan, namun Dinas Pendidikan hingga saat ini tidak menjadikan program pencegahan kekerasan terhadap anak di lingkungan sekolah sebagai prioritas utama. Sebelumnya P2TP2A telah mengusulkan agar program sosialisasi pengetahuan anak menjaga diri terhadap tindakan kekerasan dimasukkan dalam kurikulum, setidaknya menjadi muatan lokal, karena saat ini anak-anak sangat banyak dipengaruhi oleh teknologi, dan itu sangat cukup memprihatinkan. Karena banyak kasus kekerasan yang terjadi disebabkan oleh orang terdekat, di sekolah dan semakin maraknya gawai dan teknologi. Oleh sebab itu anak-anak harus dibekali kemampuan untuk menjaga dirinya.

Beberapa persoalan seringkali muncul dalam proses kolaborasi antara P2TP2A dengan Dinas Pendidikan. Misalnya, dalam rencana strategis dan rencana kerja Dinas Pendidikan, utamanya dalam Bidang Perencanaan, Evaluasi dan Pelaporan Dinas Pendidikan Kota Depok, tidak terdapat program yang secara spesifik berkenaan dengan pencegahan kekerasan anak di lingkungan pendidikan. Program yang biasanya berjalan adalah program kebijakan yang sifatnya kasuistik, artinya program hanya hadir ketika ada masalah, hal ini disebabkan karena menurut Dinas Pendidikan, program pencegahan kekerasan terhadap anak di lembaga pendidikan belum menjadi hal yang penting dan strategis untuk dimasukkan dalam rencana strategis dan rencana kerja setiap tahunnya. 
Hal lain juga ditemukan di Bidang Tenaga Pendidik dan Kependidikan Dinas Pendidikan Kota Depok, bahwa kebijakan di Dinas Pendidikan terkait dengan pencegahan tindak kekerasan di lembaga pendidikan yang difokuskan pada tenaga pendidik dan kependidikan hanyalah berupa sosialisasi kepada kepala sekolah dan guru di setiap kecamatan, kemudian sosialisasi kepada murid dan wali murid di setiap sekolah yang menjadi Sekolah Ramah Anak Kota Depok. Sosialisasi inipun tidak berlangsung rutin, hanya jika anggaran yang diajukan disetujui dan berdasarkan permintaan dari kepala sekolah yang bersangkutan.

Kondisi ini mengisyaratkan bahwa Dinas Pendidikan sebagai mitra utama P2TP2A dalam upaya pencegahan tindak kekerasan di lembaga pendidikan masih sangat parsial. Dinas Pendidikan Kota Depok cenderung aktif hanya ketika inisiatif program pencegahan tindak kekerasan di lembaga pendidikan berasal dari Dinas Pendidikan, namun dalam hal program sosialisasi tersebut berasal dari program P2TP2A atau institusi yang lain, maka Dinas Pendidikan hanya terlibat pasif. Dalam hal ini, Dinas Pendidikan tidak ikut campur dalam pelaksanaan tersebut. Meski kegiatan tersebut menyasar sekolah dan guru-guru yang notabene adalah tanggungjawab dari Dinas Pendidikan.

Kesepahaman yang sinergis belum terbangun antara P2TP2A dengan Dinas Pendidikan, sehingga masih ada tumpang tindih program dalam koordinasi dalam implementasi program. Contoh paling mudah terlihat ada pada program Sekolah Ramah Anak yang digadang oleh Pemerintah Kota Depok sebagai program unggulan. Dinas Pendidikan masih beranggapan bahwa tugas utama Dinas Pendidikan adalah menyelenggarakan proses belajar mengajar di sekolah saja. Padahal program Sekolah Ramah Anak juga mensyaratkan sekolah yang bebas dari diskriminasi dan tindak kekerasan. Bagi Dinas Pendidikan, tugas untuk mengeliminir tindakan diskriminasi dan kekerasan adalah ranah P2TP2A, bukan ranah Dinas Pendidikan. Ranah utama Dinas Pendidikan adalah menyelenggarakan pendidikan, bukan mencegah tindak kekerasan. Hal ini berdampak pada saat penganugerahan Kota Layak Anak, Kota Depok tidak memiliki Sekolah Ramah Anak. Padahal di sektor lain, misalnya Dinas Kesehatan, mereka sudah mempunyai program khusus untuk pencegahan kekerasan terhadap anak, dan betul-betul berkonsentrasi dan bertanggungjawab atas program tersebut.

Dalam satu rapat yang dipimpin oleh oleh Asisten Daerah Bidang Hukum dan Sosial Kota Depok selalu mengingatkan kepada koordinator klaster untuk 
membuat program dan kegiatan yang mendukung pengembangan implementasi program Kota Layak Anak, khususnya perlindungan anak dan pencegahan kekerasan terhadap anak di lembaga pendidikan. Dinas Pendidikan secara khusus diminta untuk secara gencar dalam melakukan sosialisasi pencegahan terhadap kekerasan anak, tidak semata tergantung pada program yang diiniasi oleh P2TP2A. Persoalan yang seringkali muncul adalah alur kerja untuk penganggaran bagi Dinas Pendidikan seringkali sangat berbelit sehingga berpengaruh pada program yang dapat dianggarkan oleh Dinas Pendidikan.

Berdasarkan penjelasan dari Kepala Sub. Bagian Perencanaan, Evaluasi dan Pelaporan (PEP) Dinas Pendidikan Kota Depok, pengkoordinasian penganggaran Dinas Pendidikan melalui konsep perumusan kebijakan merujuk pada Rencana Program Jangka Menengah Daerah (RPJMD) dan Rencana Strategis (Renstra) Dinas Pendidikan yang dibuat untuk jangka waktu lima tahun, untuk selanjutnya dituangkan dalam Rencana Kerja (Renja). Renja inilah kemudian dilaksanakan oleh setiap bidang, kemudian bidang PEP melakukan pemantauan atas implementasi kebijakan yang telah dibuat, untuk kemudian dievaluasi, apakah dalam implementasinya sudah sesuai dengan tujuan, sasaran, output dan outcome yang telah ditetapkan.

Berkenaan dengan Permendikbud No. 82 Tahun 2015 tentang Pencegahan dan Penanggulangan Tindak Kekerasan di Lingkungan Satuan Pendidikan menyebutkan tentang melindungi anak dari tindak kekerasan, mencegah anak melakukan tindak kekerasan dan mengatur mekanisme pencegahan dan penanggulangan serta sanksinya. Dalam kebijakan turunan, seharusnya Dinas Pendidikan juga memiliki program dalam rangka turunan dari permendikbud tersebut. Persoalannya, Dinas Pendidikan Kota Depok melalui bidang-bidang yang ada telah membuat program dengan memasukkan pendidikan karakter pada satuan pendidikan, dalam hal ini bagaimana guru memberikan pendidikan karakter terhadap anak didiknya. Misalnya setiap pagi guru mengajarkan untuk menyapa kepada anak didiknya, misalnya juga terdapat guru piket setiap hari yang bertugas di luar kelas untuk memastikan dan memantau murid di luar kelas, sehingga pengawasan terhadap murid terus berjalan baik di dalam maupun di luar kelas.

Model implementasi kebijakan perlindungan anak oleh Dinas Pendidikan masih terbatas hanya sebatas perlindungan formal. Bagaimana anak selamat tiba di sekolah, bagaimana kegiatan pembelajaran berlangsung, dan bagaimana dukungan sarana dan kebijakan penopang kegiatan pembelajaran. Bahkan 
dalam skema program Sekolah Ramah Anak (SRA), Dinas Pendidikan mencoba membangun semua sekolah agar ramah anak, dimulai dari tempat bermain, kurikulum, infrastruktur, dan lain sebagainya. SRA ditetapkan melalui SK Kepala Dinas tentang SRA, dan juga SK Sekolah Pendidikan Keluarga. Adanya SK ini untuk menekankan kepada sekolah untuk menjalankan program SRA, agar setiap sekolah mampu mengembangkan instrument SRA sesuai dengan kebutuhan masing-masing.

Meskipun dalam kebijakan umum Dinas Pendidikan sudah mencoba mendorong implementasi program SRA, namun implementasi tersebut baru menyentuh hal-hal teknis, belum menyentuh persoalan perlindungan anak secara psikis dan sosial. Untuk itu P2TP2A bekerjasama dengan Dinas Pendidikan mengembangkan model kolaboratif. Misalnya untuk mencegah terjadinya kekerasan terhadap murid yang dilakukan oleh guru, maka dikeluarkan kebijakan dalam rekruitmen guru Non-ASN, anggaran kegiatan tersebut disiapkan untuk guru-guru yang akan direkrut. Kolaborasi ini bahkan berjalan lebih jauh, bahwa proses seleksi yang ketat tidak hanya berlaku bagi guru, namun juga kepala sekolah. Saat ini seluruh kepala sekolah harus menjalani psikotes, guna membaca watak, baik itu yang sudah menjabat maupun yang akan manjabat. Kebijakan lainnya yang sudah diimplementasikan adalah kebijakan kurikulum yang mengharuskan kepada semua sekolah untuk menanamkan moralitas, mentalitas, dan kepribadian yang baik. Misalnya sebelum kelas dimulai, dilakukan mengaji dan berdoa bersama, dan setiap hari jumat dilakukan ceramah agama terlebih dahulu, hal ini bagian dari penanaman nilainilai moral kepada siswa.

Persoalannya adalah, program-program pencegahan kekerasan terhadap anak di lingkungan pendidikan tidak menjadi fokus utama kebijakan Dinas Pendidikan, ini ditunjukkan dari tidak adanya dalam rencana strategis Dinas Pendidikan Kota Depok, sehingga program pencegahan kekerasan hanya menjadi program turunan dari program-program yang ada dan tidak difokuskan, karenanya program-program tersebut hanya tidak menjadi rencana kerja, dan konsekuensinya program-program tersebut tidak mendapat pendanaan.

Satu-satunya program yang berkaitan dengan upaya pencegahan tindak kekerasan di lembaga pendidikan yang diselenggarakan oleh Bidang Tenaga Pendidik dan Kependidikan Dinas Pendidikan Kota Depok, yang fokus utamanya 
pada pembinaan tenaga pendidik atau guru, adalah sosialisasi kepada guru-guru dan kepala di tingkat kecamatan pada setiap awal tahun ajaran pada sebelas kecamatan di Kota Depok. Dalam program tersebut disosialisasikan bagaimana lembaga pendidikan berkepentingan untuk mencegah terjadinya tindak kekerasan pada anak di lembaga pendidikan. Selain itu juga dilakukan sosialisasi kepada murid dan wali murid pada setiap awal tahun ajaran di sekolah yang ditunjuk sebagai Sekolah Ramah Anak.

Program ini memiliki tiga persoalan serius: Pertama, program tersebut diatas adalah program turunan dari program prioritas yang ada dalam rencana kerja Dinas Pendidikan Kota Depok. Sehingga fokus implementasinya tidak secara penuh pada pencegahan kekerasan terhadap anak di lingkungan pendidikan. Hal ini ditunjukkan dari dokumen program yang menjadi acuan implementasi kebijakan. Kedua, karena program ini hanyalah program turunan, bukan program prioritas, maka keberlanjutan program ini sangat bergantung pada apakah program prioritas dalam RPJMD dan Renstra memiliki fokus pada perlindungan anak di lembaga pendidian. Sederhananya, jika pada Renstra tidak ada payung program, maka program sosialisasi ini sangat mungkin tidak dilanjutkan. Ketiga, sosialisasi ini hanya dilakukan di sekolah yang berstatus SRA, artinya, sekolah yang lain yang tidak ditunjuk sebagai SRA dapat dipastikan tidak akan mendapatkan sosialisasi tentang pencegahan kekerasan terhadap anak. Di sisi lain, bahan sosialisasi yang digunakan dalam implementasi kebijakan pencegahan adalah bahan paparan dari Mendikbud untuk pembinaan keluarga atau orangtua untuk mencegah anaknya terlibat atau menjadi korban kekerasan, namun tidak ada bahan sosialisasi untuk siswa agar terhindar dari perilaku kekerasan baik sebagai pelaku maupun sebagai korban.

Di titik ini bagaimana pentingnya kolaborasi antara P2TP2A dengan Dinas Pendidikan dalam upaya pencegahan tindak kekerasan pada anak di lembaga pendidikan. Di tahap pencegahan, P2TP2A dapat memberikan masukan bagaimana melakukan pencegahan kekerasan dalam tiga bidang: rekrutmen tenaga pendidik dan kependidikan, sosialisasi kepada siswa, dan sosialisasi kepada orangtua siswa. Dalam tahapan ini, sesungguhnya terdapat satu persoalan serius: kerjasama antara Dinas Pendidikan dan P2TP2A baru menyentuh aspek pencegahan, belum menyentuh aspek penanganan dan rehabilitas korban tindak kekerasan. Padahal ketiga aspek ini: pencegahan, penanganan, dan rehabilitasi tidak dapat dipisahkan satu sama lain. Melakukan pencegahan tanpa 
pemahaman bersama atas prosedur penanganan dan koordinasi rehabilitasi menghasilkan kebijakan yang timpang. Hal ini yang terjadi di Kota Depok, bahwa kolaborasi antara P2TP2A dan Dinas Pendidikan masih berfokus pada bagaimana mencegah, belum pada tahap prosedur penanganan dan mekanisme rehabilitasi.

Hambatan yang muncul dalam proses kolaborasi ini menunjukkan bahwa kerjasama lintas bidang, dalam hal ini P2TP2A dan Dinas Pendidikan, membutuhkan strategi khusus. Strategi ini mencakup bagaimana membangun kejaring kerjasama sekaligus mendorong upaya percepatan Depok sebagai Kota Layak Anak di Indonesia, termasuk juga bagaimana bekerjasama menjadikan kekerasan terhadap anak sebagai fokus kebijakan, sehingga dapat tertuang dalam RPJMD, Renstra, dan Renja, sehingga dapat secara optimal dianggarkan dan diimplementasikan melalui serangkaian kegiatan dan program.

\section{Kesimpulan}

Kerja kolaboratif yang dilakukan oleh P2TP2A dan Dinas Pendidikan Kota Depok sebagai pengejawantahan Perwali Kota Depok No. 43 Tahun 2017 dalam rangka pencegahan kekerasan di lembaga pendidikan, pada awalnya mendapatkan kesulitan untuk berkoordinasi dengan Dinas Pendidikan Kota Depok. Hal ini disebabkan Dinas Pendidikan Kota Depok tidak berfokus dengan tindak pencegahan kekerasan terhadap anak didik di lingkungan lembaga pendidikan. Namun dengan terjadinya beberapa kekerasan di lingkungan sekolah di Kota Depok, pada akhirnya Dinas Pendidikan Kota Depok membuka diri untuk juga ikut aktif dalam pencegahan kekerasan terhadap anak.

Setidaknya kerja kolaborasi antara P2TP2A dan Dinas Pendidikan sudah mulai muncul, melalui hadirnya program sosialisasi Setop Kekerasan Pada Anak (SKPA) dan sosialisasi "Srikandi Goes to School", hadirnya perwakilan anak dari setiap sekolah dalam Forum Anak Kota Depok, hingga keterlibatan P2TP2A dalam seleksi guru dan kepala sekolah di lingkungan Kota Depok. Dalam beberapa hal, kerja kolaborasi ini sangat positif, mengingat Depok punya masalah berat dalam pemberantasan tindak kekerasan pada anak, namun hal tersebut belum cukup.

Kendala lebih banyak hadir dalam proses kolaborasi antara P2TP2A dan Dinas Pendidikan. Misalnya, meski mebijakan Kota Layak anak yang dikeluarkan oleh Pemerintah Kota Depok, dimana P2TP2A dan Dinas Pendidikan menjadi salah satu klaster penting dalam gugus tugas tersebut, secara tidak langsung 
mengarahkan Dinas Pendidikan untuk mengeluarkan kebijakan strategis tentang pencegahan kekerasan terhadap anak di lembaga pendidikan. Namun hingga saat ini belum ada kebijakan prioritas yang dikeluarkan oleh Dinas Pendidikan Kota Depok dalam rangka pencegahan kekerasan siswa, baik itu dalam rencana strategis maupun rencana kerja tahunan. Konsekuensinya, Dinas Pendidikan belum memiliki rencana kerja yang terstruktur, melainkan hanya sporadik dan parsial. Hal ini misalnya dapat dilihat dari posisi Dinas Pendidikan yang masih masih ikut secara pasif dalam program P2TP2A ataupun hanya melaksanakan program turunan dari Renja, yang secara spesifik tidak berfokus pada upaya menurunkan angka kekerasan terhadap anak di lembaga pendidikan.

Di sisi lain, anggaran yang dimiliki oleh P2TP2A masih sangat terbatas, padahal institusi ini sangat menginginkan adanya program-program yang lebih massif dalam rangka pencegahan kekerasan terhadap anak di lembaga pendidikan Kota Depok namun masih sangat dikalahkan dengan program prioritas yang ada di Organisasi Perangkat Daerah lainnya. Di sisi lain, Dinas Pendidikan memiliki kewenangan untuk memperoleh penganggaran yang lebih besar, hanya saja Dinas Pendidikan masih belum menempatkan persoalan kekerasan terhadap anak sebagai program prioritas, sehingga program-program yang dapat dijalankan sangat sedikit, konsekuensinya ketersediaan anggaran sangat terbatas.

Kerja kolaboratif antara P2TP2A dan Dinas Pendidikan dengan demikian harus diperkuat. Penelitian ini memberikan rekomendasi agar pemerintah Kota Depok memprioritaskan program pencegahan kekerasan terhadap anak di lembaga pendidikan, baik yang dilakukan oleh P2TP2A dan Dinas Pendidikan Kota Depok. Sebab lembaga pendidikan sangat berperan penting untuk memfasilitasi tumbuh kembang seorang anak dan memberikan bekal dan pemahaman agar dapat mencegah dirinya dari tindak kekerasan baik sebagai pelaku apalagi sebagai korban. Selain itu, Dinas Pendidikan Kota Depok harus pula mencantumkan kebijakan pencegahan kekerasan di lembaga pendidikan dalam rencana kerja tahunan dan rencana strategis lima tahunan. Hal ini dikarenakan Dinas Pendidikan adalah institusi yang sangat berperan dalam menanamkan pemahaman pencegahan kekerasan kepada guru, murid dan wali murid agar kedepannya tidak terjadi lagi korban-korban kekerasan di lingkungan sekolah yang seharusnya menjadi lingkunang yang paling mendidik dan menjadi lingkungan yang paling aman buat anak untuk dapat tumbuh dan berkembang tanpa adanya ancaman-anacaman dari manapun. 


\section{Ucapan Terima Kasih}

Tulisan ini adalah bagian dari penelitian bertajuk "Penguatan dan Sinergi Multi-stakeholder Pusat Pelayanan Terpadu Pemberdayaan Perempuan dan Anak (P2TP2A) dalam Upaya Pencegahan, Penanganan dan Rehabilitasi Korban Kekerasan di Provinsi Jawa Barat" yang didukung sepenuhnya oleh Direktorat Riset dan Pengabdian kepada Masyarakat Kementerian Riset, Teknologi dan Pendidikan Tinggi Republik Indonesia. Penelitian berlangsung di lima kabupaten/kota: Kabupaten Bekasi, Kota Bekasi, Kota Bogor, Kabupaten Bogor, dan Kota Depok. Penulis mengucapkan terima kasih atas seluruh bantuan kepada seluruh pihak yang terlibat dalam proses penelitian ini.[s]

\section{Daftar Pustaka}

Afrilia, Anggita Putri. "Implementasi Program Pencegahan Kekerasan terhadap Anak di Pusat Pelayanan Terpadu Pemberdayaan Perempuan dan Anak (P2TP2A) DKI Jakarta." Skripsi tidak diterbitkan. Universitas Indonesia, 2012.

Aliyah, Himma. "Upaya Pusat Pelayanan Terpadu Pemberdayaan Perempuan dan Perlindungan Anak dalam Mewujudkan Keadilan Restoratif terhadap Rehabilitasi Korban Tindak Kejahatan Perkosaan." Skripsi tidak diterbitkan. Universitas Islam Negeri Malang, 2017.

Ardiansyah, Aco. "Implementasi Kebijakan Pelayanan Terpadu Pemberdayaan Perempuan dan Anak dalam Pencegahan Kekerasan Anak di Kota Depok." Tesis tidak dipublikasikan. Universitas Muhammadiyah Jakarta, 2019.

Fahmi, Ahadin Syarifudin. “Faktor-faktor yang Berhubungan dengan Perilaku Petugas dalam Penanganan Kasus Kekerasan pada Anak di P2TP2A (Pusat Perlindungan Terpadu Pemberdayaan Perempuan dan Anak) Kabupaten Sidoarjo." Universitas Diponegoro, 2014. http://eprints.undip.ac.id/53479/.

Hartati, Misriyani. "Studi tentang Upaya Penanganan Tindak Kekerasan terhadap Perempuan dan Anak: Studi Kasus pada Pusat Pelayanan Terpadu Pemberdayaan Perempuan dan Anak (P2TP2A) Provinsi Kalimantan Timur." eJournal Imu Pemerintahan - Fisip Universitas Mulawarman 1, no. 3 (2013).

Hendrya, Pepi. "Pemberdayaan Perempuan Korban Kekerasan dalam Rumah Tangga (KDRT), dalam Perspektif Ketahanan Individu: Studi Kasus Perempuan Korban 
KDRT Klien P2TP2A DKI Jakarta." Tesis tidak dipublikasikan. Universitas Indonesia, 2011.

Huda, Nurul. "Kekerasan terhadap Anak dan Masalah Sosial yang Kronis." Pena Justisia Jurnal Media Komunikasi dan Kajian Hukum 7, no. 14 (2008).

Komisi Nasional Anti Kekerasan terhadap Perempuan. "Lembar Fakta dan Catatan Tahunan Komnas Perempuan Tahun 2018.” Jakarta: Komnas Perempuan, 2018.

KPAI. “Laporan Tahunan Komisi Nasional Perlindungan Anak Indonesia Tahun 2017.” Jakarta: Komisi Nasional Perlindungan Anak Indonesia, 2018.

Muhammad, Muhammad. "Aspek Perlindungan Anak dalam Tindak Kekerasan (Bullying) terhadap Siswa Korban Kekerasan di Sekolah (Studi Kasus di SMK Kabupaten Banyumas)." Jurnal Dinamika Hukum 9, no. 3 (2009): 230-36. https://doi.org/10.20884/1.jdh.2009.9.3.234.

Priharyanto, Saptadi Agung. "Peran Aparat Penegak Hukum dan Pendamping Korban dalam Penanganan KDRT: Studi Kasus LBH APIK Jakarta, P2TP2A Provinsi DKI Jakarta dan Unit PPA Bareskrim Polri." Tesis tidak dipublikasikan. Universitas Indonesia, 2011.

Rizkah. S, Nur. "Kinerja Pusat Pelayanan Terpadu Pemberdayaan Perempuan dan Anak (P2TP2A) (Studi Kasus: Kekerasan Seksual di Kabupaten Sinjai)." Skripsi tidak dipublikasikan. Universitas Hasanuddin, 2016.

Rosnawati, Emy. "Peran Pusat Pelayanan Terpadu Pemberdayaan Perempuan dan Anak (P2TP2A) dalam Mengatasi Kekerasan dalam Rumah Tangga." Kosmik Hukum 18, no. 1 (2018). https://doi.org/10.30595/kosmikhukum.v18i1.2341.

Saida, Abdul Rachman. "Analisis Kinerja pada Kantor Pusat Pelayanan Terpadu Pemberdayaan Perempuan dan Anak (P2TP2A) Provinsi Sulawesi Tengah." Katalogis 3, no. 9 (2015): 54-67. http://jurnal.untad.ac.id/jurnal/index.php/ Katalogis/article/view/6418.

Yelfia, Oka. "Pengalaman perempuan dalam menghadapi kekerasan dalam rumah tangga (KDRT) di Pusat Pelayanan Terpadu Pemberdayaan Perempuan dan Anak (P2TP2A) Limpapeh Rumah Nan Gadang tahun 2015." Skripsi tidak dipublikasikan. Universitas Andalas, 2016. 